\title{
The Impact of e-Learning on the Management of Knowledge Among Faculty Members in Private Jordanian Universities
}

\author{
Hisham Ali Shatnawi \\ Faculty of Business Administration, Ajloun University, Ajloun, Jordan \\ Email address: \\ Shatnawi_hisham@yahoo.com \\ To cite this article: \\ Hisham Ali Shatnawi. The Impact of e-Learning on the Management of Knowledge among Faculty Members in Private Jordanian \\ Universities. American Journal of Operations Management and Information Systems. Vol. 4, No. 1, 2019, pp. 39-47. \\ doi: 10.11648/j.ajomis.20190401.14
}

Received: January 25, 2019; Accepted: April 16, 2019; Published: May 29, 2019

\begin{abstract}
This study aimed to identify the reality of e-learning in the three private Jordanian universities (Jerash, Ajloun and Philadelphia) and its impact on the performance of faculty members in these universities. The study society is composed of (620) faculty members in the above mentioned universities. The sample was randomly selected by 35\% sample size was (220), the study used the descriptive method and the data were collected by a questionnaire designed for this purpose. The items were composed of 40 items where the researcher created them and analyzed them. Results showed that the availability of e-learning environment was ranked first, Where the mean of the total score was (2.81) and the standard deviation (.80) and in the second place came knowledge of the concept of e-learning with an average (2.71) and a standard deviation (.77), and in the field of education outputs was in the third place with an average of (2.57) and a standard deviation (.66) and the study showed that there are no differences of statistical significance at the level $(9 \leq 0.05)$ variable, years of experience, university level and scientific qualification, except for the existence of differences of statistical significance for the variable of scientific qualification for the University of Ajloun, where the differences were significant and in favor of the scientific degree PhD on the Masters. Based on the previous results, the study has recommended a set of guidance, the most important of which: Review the policies of applying e-learning mechanisms in the light of knowledge management among faculty members.
\end{abstract}

Keywords: e-Learning, Management, Environment

\section{Introduction}

Globalization and technology, technologies have recently imposed a new world of the most important features of the explosion of the electronic revolution and the openness of the world in all its economic, political and scientific fields, which constituted a different reality. One of the most prominent features of the flow of information through the Internet, satellite channels, the proliferation of computers and cell phones, which contributed to connect individuals from different countries, cities, communities and abolished the boundaries and distances of different customs Cultures, religions, politics and brought together one small world. Information technology has worked with its various systems and techniques to connect the original knowledge and its sources to all those who wish to benefit from it and to employ them in solving the problems. It is no longer intended to communicate knowledge, but to develop, publish, store, generate and ask questions in this changing world Exaggerated possibilities and alternatives. 9Researchers found that there was an interplay between information technology and the technology of education, which led to the existence of a new reality of learning represented by its clear in the abolition of time and space and the development of new ways and methods of modern e-learning to meet the global updates of the increased demand for education with a shortage of institutions Education And increasing the quantum of information in all branches of knowledge [1]. Countries, institutions, universities and scientific centers have competed to apply e-learning in all stages and educational environments. This is the method of learning through the use of modern communication mechanisms from 
computers, networks, multimedia, voice, images, drawings, charts, forms and mechanisms. Electronic libraries and internet portals, both remotely and in the classroom.

E-learning is defined as:

Provide electronic educational content in such a way as to enable the active interaction with this content with the teacher and with his peers whether concurrently or asynchronously [5].

Through e-learning, the teacher can conduct a quick survey to determine the students' ability to experiment with the scientific material. [21]

And e-learning is the process of knowledge transfer and dissemination of various electronic media instead of conventional with the possibility of completing this learning in time, place and time and speed that fit the circumstances and capabilities of the recipient in addition to the possibility of management of this education and interaction through those media.

The teacher can use more than one illustration, such as applications on the Internet or take the student in a tour to one of the sites and explain the educational material through it directly [23]. The teacher can also divide the students into small groups that are easy to deal with and communicate with each other in audio and video to do experiments or to discuss the issues.

Through modern technology and information systems represented by the modern and advanced means of communication, communication networks provide the mechanism for transferring information and disseminating educational distance to reach the student wherever he is found (distance learning). Thus, education for all became a reality and education became all the time (education for all). As well as continuous education and self-education through advanced technological methods at a time when we find that the element of knowledge is driven by the powerful knowledge industry that is born of the scientific revolution and contemporary technology that cannot be ignored and that must be employed to provide opportunities for the use of knowledge dissemination. [18]

It is clear to the researcher that the knowledge would not have spread to if not of communication and information technology, which is the basis of access to knowledge communities and that the vast amount of information, if not computers could not be stored and retained and published.

Previous Studies:

The use of modern means and methods in the process of education, which keeps pace with technological progress, has led to the educational process using modern methods and means called e-learning, which refers to learning from the Internet and the various means of communication that reach the learner wherever it is. As to (Alhalfawi) he has defined elearning as that type of education, which relies on electronic means to achieve educational objectives and to send the educational content of the student without time and space barriers.

Al-Khan sees e-learning as an innovative way to provide an interactive environment centered around the learners and designed before starting to teach them and making it suitable for individuals according to its level using the Internet and technological techniques in accordance with the principles of educational design suitable for the environment of open, flexible and distributed education.

(Werrier) adds that e-learning is the one that provides instructional content via electronic media such as Internet, satellite, or laser discs or audio and video tapes. It can be defined as: a method of education using modern communication mechanisms such as computers, networks and multimedia to deliver information to learners in a faster and less cost.

To achieve the process of e-learning there must be available elements of such education and it consists of:

E-learner:

1. A student : who receives information through elearning.

2. teacher: He supervises the process of e-learning and interact with learners and directs the process of education.

3. Electronic Semester: The classrooms are equipped with some devices and means that serve the teaching process.

4. E-book: It is the educational curriculum similar to the textbook and may include the written text, pictures, videos and drawings. It makes the content of the educational more fun and more obvious to the student. It may be found in the Internet or copied on a magnetic cylinder and libraries. And the imaginary classes simulate the real chapter is programmed and placed on a special page on the Internet so that the students and the teacher meets at a specific time and interact with them electronically like speaking reality.

As for the types of e-learning, Abdul Hamid 2007 has four categories or levels:

1. enrichment e-learning (Enrichment level) means the use of the Internet as a source of general and specialized information and distributed on different sites and benefit the learner in supporting the achievement of education and acquisition of skills, a level based on the learner's desire to develop his knowledge or information.

2. Supplementary e-learning (supplement level) In this type of learning, learning is done within the traditional classroom, but it is learned from the network, it is used as a resource for learning resources and special experiences that are designed, produced, and made available on the Web.

3. Basic e-Learning (Essential level ) This type depends on the Internet or the web in education where the system is built and the provision of requirements, then the design of courses and teaching tools and methods of interaction and made available in the sites of the educational institution on the Internet.

4. Integrated e-Learning (integrated level) This type adds to the previous types digital photography for the teacher and his explanation, it is available on the site and interaction and communication simultaneously or not 
synchronously in addition to access to digital libraries, laboratories, museums and others.

Mousa Tawfiq mentions that e-learning is divided into:

1. conductive education: it Is an education on the air (synchronous e-learning ) that needs to have learners at the same time in front of the computers to hold discussion and conversation (chatting ) between the students themselves and between the teacher through the chat room (virtual classroom) or receive lessons through the virtual classroom.

2. Asynchronous e-learning: Which is the indirect education that does not require the presence of learners at the same time or in the same place and is done through some techniques of e-learning such as e-mail where the exchange of information between the students themselves and between them and the teacher in consecutive times and the learner selects the time and places to suit him.

\section{Difficulties Facing e-Learning}

(Eyadat) mentioned that there are a number of challenges facing faculty members, including the electronic environment that imposed the conversion on the teacher from the traditional environment to the electronic, which requires dealing with a lot of educational programs Based on the computer and the type of information and technology that is choose to fit e-learning and the way to write questions that raise creative debate to facilitate the process of dialogue. Elearning has led to the rapid development of the educational process, which requires the teacher to follow this development from all aspects of knowledge and technology, and what applies to the teacher applies to the student learner.

E-learning has many and many obstacles. The preference of many faculty members for the traditional style at the expense of e-learning, the lack of training and rehabilitation for teachers on this type of education and the lack of understanding of faculty members of individual differences and differences between Students of one grade and the importance of the method of teaching and working in technology over the development of knowledge of the request.

Despite the obstacles to e-learning, there are a number of benefits, including:

1. Increase the opportunity for communication between teacher and student.

2. The article can be explained at any time and it could be reviewed any time.

3. It gives a sense of equality among all students.

4. Give the student an unobstructed view

Knowledge management:

Knowledge management is defined as finding a way to facilitate the access of the employees of the organization to knowledge and then put it at the disposal of all (Alaydrous) [11] describe the results as a processed From any place whether in documents, databases or in the minds of employees to add value to the organization through innovation, application and integration of knowledge, or in the diagnosis, acquisition, generation, storage, development, distribution and application of knowledge in the organization.

(Zack 2009) defined it as a term related to processes or stages in order to find, publish, test and use knowledge for useful purposes.

(Park 2004) believes that knowledge management is a system of knowledge acquisition based on competitive capacity, storage and distribution for the benefit of the organization. (Regules 2008) said that knowledge management is a tool to create or add value by increasing the effectiveness of the use of skills and expertise organized or outside.

The quality of decisions taken at all levels of management depends on the quality, accuracy and correctness of the information available and accuracy that can be obtained using modern and sophisticated systems that provide data, analyze, store and deliver it to organizational decision makers.

In terms of knowledge sources (Tawfeeq) [3] agreed that the knowledge sources are divided into two categories:-

1. Internal sources: It is the internal environment of the institution and the experiences of the workers and their experiences and accumulated experience of individuals, information and knowledge that are learned by individuals during their work in the Foundation.

2. External sources: The external environment of the organization, which includes research centers, conferences, seminars, the Internet, newspapers, magazines, universities, research centers, competitors, teachers, laws and regulations, as well as customers, trainers and others.

Study problem:

Recent developments in technology, universities and knowledge have forced universities and educational institutions to respond to the changes and developments that have characterized education as other fields of knowledge And it has become imperative for organizations to transfer knowledge electronically to save time and effort and raise the achievement and as e-learning may increase the demand for the acquisition in the light of technological development And contributes to the management of knowledge which is the basis of taking advantage of the knowledge and experience that exists in individuals. The Jordanian universities had to change and did their best to keep pace with this modernity. However, educational practices in this system have not yet been formed and have not developed as required. Therefore, the study problem lies in answering the following questions

1. What is the reality of e-learning in Jordanian universities and its impact on knowledge management?

2. Are there significant statistical differences at the level of the degree of $(9<=0.05)$ of the reality of e-learning in Jordanian universities and its impact on the management of knowledge among faculty members?

\section{Hypotheses of the Study}

The first hypothesis:

There were no statistically significant differences at the 
level $(9<=0.05)$ in the average responses of the sample members of the study to the reality of e-learning in the private Jordanian universities in the light of the knowledge management of the faculty members.

The second hypothesis

There are no statistically significant differences at the level of the mean $(9<=0.05)$ in the average response of the study sample members to the reality of e-learning in the private Jordanian universities in the light of the knowledge management of the faculty members.

The third hypothesis

There are no significant statistical differences at the level of statistical significance $(9<=0.05)$ in the average responses of sample members of the study of the reality of e-learning in Jordanian private universities in the light of the management of knowledge among faculty members.

The importance of the study

The importance of this study lies in that it may contribute to:

1. Highlighting e-learning in Jordanian universities is a new challenge for university education.

2. Provide a new style of educational processes based on raising the modern technologies and applications with courses to be available in any place and time, which improves the results of the process of e-learning and its quality.

3. The scarcity of studies on the reality of e-learning in Arab libraries and the importance of knowledge management in university education.

4. Enriching the Arabic library with qualitative studies may serve researchers and academics in this field.

5. Providing information to the heads of Jordanian universities, deans and department heads on e-learning and its obstacles. The study will provide a new approach to e-learning and knowledge management.

6. The student and faculty benefited from the results of the study

7. The study may be the nucleus of other studies and reference framework for them.

\section{Objectives of the Study}

Disclosure of the reality of e-learning in Jordanian universities and their impact on the management of knowledge in it and determine the objectives of the sub-study:

1. Detection of statistical differences in the average response rate for the reality of e-learning at private Jordanian universities.

2. The impact of e-learning on the management of knowledge among faculty members in private Jordanian universities.

3. Investigating the reality of e-learning in private Jordanian universities and highlighting the most important obstacles facing this education.

4. To make recommendations to decision-makers at these universities to develop e-learning and develop knowledge management and decision-making.

Terminology
E-learning: is an educational domain based on information and communication technology through the use of the Internet and computer technologies and modern communications devices and programs and electronic systems prepared by modern specialists in e-learning.

Knowledge Management: is defined as a set of strategies and processes that organize all aspects of man's data and information, ideas of abilities and trends, whether in the past or present.

\section{Limitations of this study}

Spatial boundaries: The limits of this study were limited to the sample of Jordanian private universities (Jerash, Ajloun and Philadelphia).

Time Limits: This study was conducted in the first semester of the academic year 2018-2019.

\section{The study sample}

The study sample was randomly selected from (155) members of the faculty members of the three universities (Jerash, Ajloun, Philadelphia), of which 220 males and 55 females, The following table shows the distribution of the study sample based on their demographic variables:

Table 1. The distribution of the study sample based on their demographic variables.

\begin{tabular}{lll}
\hline Sex & number & Percentage \\
\hline Male & 165 & $75 \%$ \\
Female & 55 & $25 \%$ \\
All & 220 & $100 \%$ \\
Scientific qualification & number & percentage \\
Ph.D. & 202 & $92 \%$ \\
M.A & 18 & $0.80 \%$ \\
All & 220 & $100 \%$ \\
Teaching experience & number & percentage \\
5years $>$ & 77 & $36 \%$ \\
5-15 years & 98 & $44 \%$ \\
5 years $<$ & 45 & $20 \%$ \\
All & 220 & $100 \%$ \\
university & number & Percentage \\
Ajloun & 50 & $22 \%$ \\
Philadelphia & 95 & $43 \%$ \\
Jerash & 75 & $34 \%$ \\
All & 220 & $100 \%$ \\
\hline
\end{tabular}

\section{Study tool}

The study tool used by the researcher was prepared for the purpose of identifying the impact of e-learning on the management of knowledge among faculty members in private Jordanian universities.

Where the researcher used literature and previous studies and experts with the competence in the design of the questionnaire and determine the appropriate question formats, The Likert Quintet was chosen as the final figure in 49 items divided into three areas as in the following table

Table 2. Likert Quintet was chosen as the final figure in 49 items.

\begin{tabular}{lll}
\hline $\begin{array}{l}\text { The number in } \\
\text { the questionnaire }\end{array}$ & Field & Number \\
\hline $1-22$ & Understanding the concept of e-learning & 1 \\
$35-23$ & Availability of e-learning environment & 2 \\
$49-36$ & E-learning outputs & 3 \\
49 & Degree & \\
\hline
\end{tabular}




\section{Credibility of the questionnaire}

The questionnaire was presented to a group of arbitrators with expertise and competence in the fields of scientific research and they gave the truth of the scale and its validity for the purposes of this research.

Stability of the questionnaire

The stability of the administration was confirmed by conducting the internal consistency test and extracting the (Kronbach alpha) coefficient on the entire study sample as shown in the following table 3

Table 3. Stability coefficient for the fields of study.

\begin{tabular}{lll}
\hline $\begin{array}{l}\text { Stability } \\
\text { coefficient }\end{array}$ & Field & Number \\
\hline 86.7 & Understanding the concept of e-learning & \\
80.2 & Provides an electronic learning environment & \\
90.3 & E-learning outputs & \\
93 & Total degree & \\
\hline
\end{tabular}

\section{Study Procedures}

In order to carry out the study, the researcher carried out the following procedures:-

1. Preparing a questionnaire with the aim of identifying the impact of e-learning on the management of knowledge among faculty members in private Jordanian universities.

2. To contact the competent experts in the field of scientific research to determine the validity of the study tool and based on their guidance came out as final.

3. The study population was identified, which includes three Jordanian universities, Ajloun, Jerash, and Philadelphia.

4. The questionnaire was distributed to the sample and the sample was randomized. (250) questionnaires were distributed, (230) were retrieved and (10) were excluded. The result was (220) questionnaire.

5. Responses were discharged and results were extracted using statistical treatments.

Study Variables:

The study included two types of variables:

First: Independent variables

1. Sex variable (Male, Female)-

2. Scientific qualification variable (Master, Ph.D )

3. Years of experience variable (less than 5 years, 5-10 years, more than 10 years).
4. -Universities variable (Ajloun, Jerash, Philadelphia)

Second: dependent variables:

It assimilate the response of members of the sample on the management items.

Statistical Processing:

The statistical processing was done using the statistical packages program (SPSS) which was:

1. Extraction of arithmetical averages and standard deviations of questionable verbs.

2. Extraction of Percentages for Sample Study Subjects by Research Variables.

3. Use of the test (T) and the test of the analysis of the mono-variance to examine the hypotheses related to the study variables.

\section{Management correction}

The following distribution of items was adopted in the process of correcting the study tool items and extracting the results according to the method of (Likert pentagram) in addition to dividing them to the next levels:

Table 4. Gradient scale of (Likert pentagram) for the items of the questionnaire.

\begin{tabular}{lllll}
\hline $\begin{array}{l}\text { Very few } \\
\text { gradient }\end{array}$ & $\begin{array}{l}\text { Few } \\
\text { gradient }\end{array}$ & $\begin{array}{l}\text { Medium } \\
\text { gradient }\end{array}$ & $\begin{array}{l}\text { Large } \\
\text { gradient }\end{array}$ & $\begin{array}{l}\text { Very large } \\
\text { gradient }\end{array}$ \\
\hline 1 & 2 & 3 & 4 & 5 \\
\hline
\end{tabular}

And to extract the arithmetic mean and the correction key statement, table 5 shows this:

Table 5. The arithmetic mean and the correction key statement.

\begin{tabular}{ll}
\hline Degree & Arithmetic mean \\
\hline Very low & $>1.8$ \\
Low & $1.8-2.59$ \\
Average & $2.6-3.39$ \\
High & $3.4-4.19$ \\
Very high & $4.2<$ \\
\hline
\end{tabular}

\section{Study Results and Discussion}

In order to facilitate the interpretation of the results, the study was based on the percentages.

First: Results related to the question of the first study on the reality of e-learning in Jordanian universities and its impact on knowledge management. To answer this question, the arithmetical averages, standard deviations and percentages of the field were extracted on Table 6

Table 6. The arithmetical averages, standard deviations and percentages of the field.

\begin{tabular}{|c|c|c|c|c|}
\hline No. & Items & Mean average & Standard deviation & percentage \\
\hline 17 & E-learning contributes in presenting educational materials in a better way. & 4.17 & 0.71 & 83.4 \\
\hline 4 & E-learning enables students and professors to communicate better. & 4.13 & 0.70 & 82.55 \\
\hline 7 & E-learning is accompanied by qualitative development in education. & 4.12 & 0.69 & 82.43 \\
\hline 9 & The application of e-learning encourages the emergence of new patterns of education. & 4.10 & 0.67 & 82.07 \\
\hline 3 & E-learning helps to increase motivation for teachers to work. & 4.02 & 0.63 & 80.49 \\
\hline 2 & E-learning techniques contribute to the efficiency of teachers. & 3.99 & 0.66 & 79.88 \\
\hline 1 & E-learning is accompanied by quality education. & 3.99 & 0.62 & 79.76 \\
\hline 20 & E-learning contributes to an increased motivation for teachers. & 3.98 & 0.75 & 79.57 \\
\hline 13 & E-learning contributes to 79.27 increasing educational experiences. & 3.98 & 0.73 & 79.51 \\
\hline 16 & E-learning raises student motivation towards education. & 3.96 & 0.71 & 79.27 \\
\hline
\end{tabular}




\begin{tabular}{|c|c|c|c|c|}
\hline No. & Items & Mean average & Standard deviation & percentage \\
\hline 11 & Contributes to the determination of teachers' accounts for advanced technology. & 3.88 & 0.72 & 77.51 \\
\hline 10 & Contributes in facilitating the understanding of students. & 3.84 & 0.73 & 76.72 \\
\hline 12 & Contributes in providing a highly qualified feeder to raise the efficiency of trainers. & 3.80 & 0.71 & 76.05 \\
\hline 19 & Participates in building training programs according to the needs of instructors. & 3.79 & 0.72 & 75.87 \\
\hline 22 & Contributes in identifying the requirements of the courses. & 3.69 & 0.84 & 73.74 \\
\hline 18 & Reduces the burden of the teaching staff. & 3.68 & 0.84 & 73.68 \\
\hline 8 & Provides equal opportunities for all students. & 3.56 & 0.84 & 71.12 \\
\hline 5 & Reduces physical contact between students and teachers. & 3.50 & 0.92 & 69.97 \\
\hline 6 & Increases the required burdens of faculty members. & 3.48 & 0.95 & 69.6 \\
\hline 21 & Not suited for current cum printed courses. & 3.40 & 0.90 & 67.96 \\
\hline 14 & E - learning reduces behavioral crises. & 3.35 & 0.85 & 76.05 \\
\hline 15 & E-learning leads to lesser relations between students. & 3.31 & 0.94 & 66.26 \\
\hline
\end{tabular}

The results of the previous table 6 show that the paragraph which states (e-learning contributes in presenting educational materials better than traditional materials) Has received the highest arithmetic mean with an average of (4.17) and the result of (education leads to lesser social relations between the student) with the lowest average account (3.31). Hence, the degree of awareness of the concept of e-learning can be interpreted as the general arithmetic average of responses (3.81) is high.

The arithmetical averages and standard deviations of the elearning environment are shown in the table below:

Table 7. The arithmetical averages and standard deviations of the e-learning environment.

\begin{tabular}{lllll}
\hline$\#$ & Item & Arithmetic average & Standard deviations & percentage \\
\hline 10 & E-learning needs a high cost. & 4.17 & 0.82 & 83.47 \\
12 & E-learning provides time and effort in learning processes. & 4.02 & 0.82 & 80.36 \\
7 & Lack of computer hardware helps students learn more easily. & 3.99 & 0.95 & 79.82 \\
6 & There is no technical support team to solve the problems of learners during teaching. & 3.98 & 0.92 & 79.64 \\
11 & Lack of equipped classrooms contributes in the low level of education. & 3.98 & 0.97 & 79.51 \\
9 & Lack of electronic libraries delays the process of education. & 3.98 & 0.93 & 79.51 \\
1 & weak equipped classrooms for e-learning. & 3.97 & 0.90 & 79.45 \\
2 & Qualified teachers are not enough for e-learning education. & 3.86 & 0.91 & 77.20 \\
8 & Electronic interaction provides knowledge more easily. & 3.86 & 0.83 & 77.14 \\
4 & Lack of effective teaching strategies in e-learning. & 3.83 & 0.80 & 76.66 \\
3 & Electronic educational programs do not considerate the differences between the student. & 3.82 & 0.82 & 76.41 \\
13 & Having a website (portal ) helps to develop education. & 3.79 & 1.27 & 75.81 \\
5 & Weak access and connections to the internet in the private universities. & 3.61 & 1.14 & 72.28 \\
- & Total degree & 3.91 & 0.93 & 78.252 \\
\hline
\end{tabular}

It is clear from the results of the previous table 7 that the item that states (e-learning needs a high cost of infrastructure processing) has obtained the highest arithmetical mean which is (4.17), While the item that states (the weakness of the possibilities of private universities and their connection to the Internet) was at the lowest of the arithmetic average (3.61). The degree of availability of the e-learning environment can be explained as the general arithmetic average, where the general arithmetic average of respondents' responses (3.91) which is high. The researcher attributes this to the availability of an appropriate environment for e-learning in Jordanian private universities from laboratories and the Internet.

As for the outputs of e-learning, the following table explains it:

Table 8. The arithmetical averages and standard deviations of e-learning output field.

\begin{tabular}{|c|c|c|c|c|}
\hline \# & Items & Arithmetic average & Standard deviation & percentage \\
\hline 3 & E-learning improves educational climate to provide alternative electronic media. & 3.96 & 0.65 & 79.27 \\
\hline 1 & E-learning enhances student control in the educational process. & 3.94 & 0.70 & 78.72 \\
\hline 5 & E-learning enhances the skills of students. & 3.93 & 0.68 & 78.54 \\
\hline 2 & E-learning helps to use all available learning styles. & 3.91 & 0.66 & 78.24 \\
\hline 13 & It develop creative skills and creative thinking. & 3.86 & 0.77 & 77.26 \\
\hline 6 & Provides e-learning time through virtual classes. & 3.85 & 0.73 & 77.08 \\
\hline 12 & Electronic learning contributes to the application of academic knowledge. & 3.81 & 0.71 & 76.23 \\
\hline 10 & E-learning increases the sharing of knowledge between students and universities. & 3.81 & 0.75 & 76.17 \\
\hline 11 & e-learning helps in developing community. & 3.78 & 0.84 & 75.62 \\
\hline 4 & E-learning employs all concepts of educational system. & 3.75 & 0.72 & 75.02 \\
\hline 8 & E-learning helps reduce classroom congestion. & 3.74 & 0.88 & 74.77 \\
\hline 9 & E - learning helps students learn to solve electronic problems. & 3.69 & 0.78 & 73.74 \\
\hline 7 & E - learning helps in satisfying the moral values through knowledge & 3.34 & 0.91 & 66.75 \\
\hline 14 & E-learning takes into consideration the individual circumstances of the students. & 3.29 & 0.96 & 65.90 \\
\hline- & Total degree & 3.76 & 0.77 & 75.24 \\
\hline
\end{tabular}


It is clear from the results of the previous table that the item that states ( $\mathrm{E}$ - learning improves educational climate to provide alternative electronic media) has obtained the highest arithmetic averages and it was (3.96) While the item that states (E-learning takes into consideration the individual circumstances of the students) the lowest arithmetic average
(3.29) and the degree of output e-learning responses of respondents (3.79) which is high, the researcher believes that the existence of e-learning in private Jordanian universities is effective.

The reality of e-learning in private Jordanian universities is illustrated in the following table

Table 9. Statistical averages and standard deviations of the fields of study on the reality of e-learning in Jordanian private universities.

\begin{tabular}{|c|c|c|c|c|}
\hline Fields & Items & Statistical average & Standard deviation & Percentage \\
\hline First & Understanding the concept of e - learning & 3.81 & 0.76 & 76.11 \\
\hline Second & The availability of e-learning environment & 3.91 & 0.93 & 78.25 \\
\hline third & E-learning outputs & 3.76 & 0.77 & 75.24 \\
\hline- & Total field & 3.83 & 0.82 & 76.53 \\
\hline
\end{tabular}

The second field (the availability of e-learning environment) obtained the highest arithmetic mean (3.91), while the third field (e-learning outputs) obtained the lowest arithmetic averages (3.76) the arithmetic mean of the total field was high (3.83). The researcher attributed this to the availability of an environment suitable for e-learning in private Jordanian universities.

Second, the results related to the second question, are there any differences of statistical significance at the level $(9<=0.05)$ of the indication of the reality of e-learning in private Jordanian universities?

It is summarized in the following:

Table 10. Study sample of the independent variable of the reality of e-learning in Jordanian universities - gender variable.

\begin{tabular}{|c|c|c|c|c|c|c|c|}
\hline \multirow{7}{*}{ Total Area } & University & gender & Numb & Arithmetic average & Standard Deviation & (T) value & Significance Level \\
\hline & \multirow[b]{2}{*}{ Ajloun } & Male & 46 & 3.81 & 0.35 & & \multirow{3}{*}{$\begin{array}{l}0.95 \text { earning outputsf } \\
\text { learning enviroment-e }\end{array}$} \\
\hline & & Female & 8 & 3.62 & 0.31 & 0.07 & \\
\hline & \multirow{2}{*}{ Jerash } & Male & 59 & 3.82 & 0.39 & \multirow{3}{*}{1.40} & \\
\hline & & Female & 16 & 3.70 & 0.44 & & 0.16 \\
\hline & \multirow{2}{*}{ Philadelphia } & Male & 75 & 3.86 & 0.32 & & \\
\hline & & Female & 20 & 3.79 & 0.29 & 0.80 & 0.43 \\
\hline
\end{tabular}

$(9<=0.05)$ Statistical data in

Based on the $(\mathrm{T})$ test, it is found that the value of the mean level is greater than (0.05) and is not a statistical indication for the three universities. Therefore, zero hypothesis was accepted that there is no statistically significant differences at the level of statistical mean $(9<=0.05)$, In the average responses of the study sample members to the reality of elearning in the Jordanian private universities according to the gender variable.

The researcher attributed the reason for this to the similarity of the conditions of Jordanian private universities in the possibilities, social and economic conditions of the country, especially the universities of the north, which are far from the capital Amman and because the technological development is imperative to the members of the faculty to communicate with their students through various electronic services.

The second hypothesis test There are no statistically significant differences in the level of statistical significance $(9<=0.05)$ in the average responses of the sample members of the study of the reality of e-learning in the private Jordanian universities in the following table.

Table 11. Statistical averages and standard deviations of the reality of e-learning in Jordanian universities on knowledge management.

\begin{tabular}{|c|c|c|c|c|c|}
\hline Field & University & Years of experience & num & Statistical average & Standard Deviation \\
\hline \multirow{4}{*}{ Total degree } & \multirow{4}{*}{ Ajloun } & $<5$ years & 12 & 3.79 & 0.35 \\
\hline & & $5-10$ years & 15 & 3.77 & 0.37 \\
\hline & & $10<$ years & 23 & 3.92 & 0.31 \\
\hline & & Total & 50 & 3.84 & 0.35 \\
\hline \multirow{3}{*}{ Total degree } & \multirow{3}{*}{ Jerash } & $5>$ years & 16 & 3.79 & 0.34 \\
\hline & & $5-10$ years & 25 & 3.72 & 0.48 \\
\hline & & $10<$ years & 34 & 3.82 & 0.38 \\
\hline \multirow{4}{*}{ Toatal Degree } & \multirow{4}{*}{ Philadelphia } & $5>$ years & 24 & 3.68 & 0.32 \\
\hline & & $5-10$ years & 32 & 3.82 & 0.24 \\
\hline & & $10<$ years & 39 & 3.80 & 0.37 \\
\hline & & Total & 95 & 3.84 & 0.31 \\
\hline
\end{tabular}

Based on the $(\mathrm{T})$ test, it is found that the value of the mean level is greater than (0.05) and is not a statistical indication for the three universities. Therefore, zero hypothesis was accepted that there is no statistically significant differences at 
the level of statistical mean $(9<=0.05)$, In the average responses of the study sample members to the reality of elearning in the Jordanian private universities according to the gender variable.
As for the analysis of the mono-variance (One way analysis of variance) of the reality of e-learning at the private Jordanian universities, the following table illustrates this.

Table 12. The reality of e-learning at the private Jordanian universities.

\begin{tabular}{|c|c|c|c|c|c|}
\hline \multirow{2}{*}{$\begin{array}{l}\text { Total degree for } \\
\text { university variable }\end{array}$} & \multirow{2}{*}{ Source of contrast } & \multirow{2}{*}{ Total squares } & \multirow{2}{*}{$\begin{array}{l}\text { Freedom } \\
\text { Degree }\end{array}$} & \multirow{2}{*}{$\begin{array}{l}\text { (F) } \\
\text { value }\end{array}$} & \multirow{2}{*}{ Significance level } \\
\hline & & & & & \\
\hline \multirow{3}{*}{ Ajloun } & Between groups & 0.5 & 2 & \multirow{3}{*}{2.11} & \multirow{3}{*}{0.13} \\
\hline & Within groups & 12.35 & 50 & & \\
\hline & Total & 12.85 & 70 & & \\
\hline \multirow{3}{*}{ Jerash } & Between groups & 0.2 & 2 & \multirow{3}{*}{0.06} & \multirow{3}{*}{0.55} \\
\hline & Within groups & 17.85 & 75 & & \\
\hline & Total & 18.05 & 77 & & \\
\hline \multirow[t]{2}{*}{ Philadelphia } & Within groups & 10.45 & 95 & \multirow[t]{2}{*}{0.43} & \multirow[t]{2}{*}{0.65} \\
\hline & Total & 10.54 & 97 & & \\
\hline
\end{tabular}

Based on the mono-variance test, it was found that the value of the signatory level is greater than (0.05) and therefore is not a statistical method to accept the zero hypothesis which says that there is no significant statistical difference at the level $(9<=0.05)$ of statistical significance in the average responses of the survey sample, e-learning in the Jordanian private universities depending on the variable years of experience the researcher attributed that to the slow progress in the growth of these universities being in the residential areas compared to the capital, And the cognitive reality imposed on the members of the faculty to adapt to e-learning, whether the years of experience they have is few or many.

The reality of e-learning according to the scientific qualification

Table 13. Results of the (t-test) of the reality of e-learning in Jordanian private universities according to the variable of scientific qualification of teachers in it.

\begin{tabular}{|c|c|c|c|c|c|c|c|}
\hline Field & University & $\begin{array}{l}\text { Scientific } \\
\text { qualification }\end{array}$ & NUM & $\begin{array}{l}\text { Statistical } \\
\text { average }\end{array}$ & $\begin{array}{r}\text { Standard } \\
\text { deviation }\end{array}$ & $\begin{array}{l}\text { (T) } \\
\text { value }\end{array}$ & $\begin{array}{l}\text { Significance } \\
\text { level }\end{array}$ \\
\hline \multirow{6}{*}{$\begin{array}{l}\text { Total } \\
\text { Field }\end{array}$} & \multirow[t]{2}{*}{ Ajloun } & Master & 6 & 3.85 & 0.3 & \multirow{2}{*}{0.45} & \multirow{2}{*}{0.66} \\
\hline & & PH.D & 44 & 3.51 & 0.35 & & \\
\hline & \multirow[t]{2}{*}{ Jerash } & Master & 13 & 3.82 & 0.5 & \multirow{2}{*}{0.62} & \multirow{2}{*}{0.56} \\
\hline & & PH.D & 65 & 3.75 & 0.38 & & \\
\hline & \multirow[t]{2}{*}{ Philadelphia } & Master & 18 & 3.7 & 0.32 & \multirow{2}{*}{2.5} & \multirow{2}{*}{0.01} \\
\hline & & PH.D & 77 & 3.78 & 0.33 & & \\
\hline
\end{tabular}

In reference to the test of the samples, it was found that the value of the mean level is greater than (0.05) and therefore is not statistically significant for Ajloun and Jerash Universities Therefore, the zero hypothesis is accepted according to the absence of statistically significant conditions at the level of statistical significance $(9<=0.05)$ in the average responses of the study sample members to the reality of e-learning in private Jordanian universities and their impact on the management of knowledge among teachers, according to the variable of scientific qualification for the universities of Ajloun and Jerash, while the existence of differences in the statistical significance at the level of statistical significance $(9<=0.05)$ for the University of Philadelphia which rejects the hypothesis of zero for this university.

And the differences were significant for $\mathrm{PhD}$ holders it benefits them on the master, which is attributed to the nature of the university system, which has a doctoral campaign the opportunity to participate in external conferences, which enriched their knowledge in e-learning more.

Results and Recommendations

In the light of the results of the research and the statistical analysis of the views of the study sample, the study was drawn into a set of recommendations and results:

1. The results show that Jordanian private universities are seeking fast steps towards e-learning after the Ministry of Higher Education allowed each subject to have 20\% electronic education.

2. E-learning achieves from working hours for teachers and students, and from the operating costs of university energies and its expenses. Therefore, it became an urgent desire of the universities.

3. Technology has imposed a new reality that facilitates the adoption of e-learning for Jordanian private universities.

4. Telecommunications companies and Internet service providers have provided the communication process and facilitated it to members of the community and because of the rejection of the prices universities benefit from these services in the field of e-learning.

5. Revisiting university education policies related to elearning based in knowledge management.

6. Implementing e-learning under clear and unified strategic plans and linking the knowledge of e-learning and the techniques of acquisition and implementation.

7. To support and develop of e-learning environment in all Jordanian universities.

8. Keeping pace with the electronic development of elearning in educational processes.

9. The need to help faculty members identify their needs in a 
manner consistent with the nature of the technology used.

\section{References}

[1] Albalawi Fatima Mohammed (2006) e-learning Riyadh KSA Aldar alsawtyah for publishing and distribution.

[2] Altawdari Awad (2004), Electronic school and the roles of modern teacher. Jedah.

[3] Tawfeeq, Salah aldeen, Hani Mousa (2007), The role of elearning in the building of Arab society, Journal of the Faculty of Education in Shebin El Koum University of Menoufia.

[4] Aljarf,. Reema Saad Saadeh (2008), Requirements for the Transition from Traditional to E-Learning, College of Languages and Translation, King Saud University KSA.

[5] Alharethi Mohammed Bin Atieh (2006), Instructional Technologies and their Actual Use in Teaching, Journal of Communications Vol. 19, Issue X, Aleppo.

[6] Alharbi Bushra (2012), The reality of using e-learning from the perspective of students of the Department of Educational Technology, King Saud University, Master Thesis unpublished.

[7] Husamo, Suha (2011) The reality of e-learning at Tishreen University from the point of view of faculty members.

[8] Alhalfawi, Waleed Bin Salem (2006), Innovations of technology education in the information age.

[9] Alhawamdeh Mohammed Fuad (2011), Obstacles to the use of learning.

[10] eyadat, Yousef Ahmed (2005), E-learning obstacles, challenges and solutions.

[11] Alaydrous, agadeer (2012), Knowledge Management: Arab vision and strategy.

[12] Alkbaysi, Amer (2005), Knowledge Management and Organizational Development, First Edition.
[13] Allawh, Ahmed Hasan and Yehya Atwah (2011), Obstacles facing faculty members.

[14] Park. h Ribier. V \& Schult, W. D (2004) " critical attributes of organizational culture that promote knowledge management technology implementation" Journal of knowledge management.

[15] Warrier B. (2011), bringing about a blend of e-learning and traditional methods. Indias national newspaper.

[16] Weaver, Pete E. (2004), Avoiding e-learning failure: proceeding of international conference on computers yoon, SWand lim Strtigic blending.

[17] Zack Singh M. \& Mckeen (2009), knowledge management and organizational performance.

[18] Leem junghoom (2012), the current statues of elearning and stratigies to enhance educational competitives in Korean higher education.

[19] Ruggles R. (2008) The state of nation: knowledge management in practice, California management review, Vol (4), No (3).

[20] Singh, Satyendra (2008), the development and investigation on a conceptual model to understand knowledge management Ph.D. Dissertation, Queens university.

[21] Pioneers of Palestinian e-learning, Iman Abu Humaid, Dar Al - Messier Publishing \& Distribution, Amman 2018.

[22] E-learning environments for gifted students, Mustafa Abou El Nour Mostafa, Dar Wael for Publishing, Amman, 2017.

[23] E-learning Skills in Iraq, Salem Mohammed, Baghdad Journal, ISSN: 207277, 2018 Issue: 17 pages 275-306.

[24] The importance of e-learning in teaching, Mowafaq Hamed Snawi Dar Al - Furqan for Publishing, AMMAN 2016.

[25] E-learning and its impact on teacher training, Salem Mahmoud Abboud, Dar Wael Publishing Amman, 2017. 